\section{Parent Engagement in Reclassification for English Learner Students with Disabilities}

\author{
Jamey Burho \& Karen Thompson
}

Oregon State University
Journal of Family Diversity

in Education, 2021

Vol. 4, No. 1, pp. 20-41

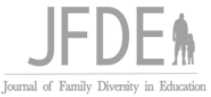

\begin{abstract}
Laws governing special education services and EL services specify different roles for parents in educational decision-making. Little research exists on home-school communication for families of English learner students with disabilities (ELSWDs), who are navigating both sets of services. We conducted six case studies of ELSWDs to examine parents and educators' communication about educational services and, specifically, how parents were engaged in decisions about whether students should be reclassified and exit EL services. Findings suggest that educators conveyed information to parents using a one-way transmission approach (Nichols \& Read, 2002). Parents often had incomplete or inaccurate information about their children's services, had questions and concerns that they did not voice to educators, and sought out non-school sources to inform their decision-making.
\end{abstract}

Keywords: English learners, special education, reclassification, parent engagement

\title{
Introduction
}

English learners (ELs) are expected to be reclassified as "proficient" in English at some point during their K-12 schooling, and thus exit EL services. However, English learner students with disabilities (ELSWDs) may have special needs that impact their performance on English language proficiency (ELP) assessments, on which EL reclassification decisions are typically based. At the secondary level, ELSWDs are less likely than ELs without disabilities to attain the test-based criteria necessary to exit EL services, a phenomenon which results in a reclassification bottleneck (Umansky et al., 2017). This bottleneck is problematic for many reasons, including the fact that ELSWDs are often enrolled in two types of non-credit-bearing courses-special education classes and classes focusing on English acquisition (e.g., English Language Development [ELD] or English as a Second Language [ESL]). This academically marginalized population consequently faces even greater risks for not earning enough credits to graduate and missing out on high-interest electives.

For all students with disabilities, including ELSWDs, the Individuals with Disabilities Education Act (IDEA, 2015) specifies that parent engagement is a crucial, required component of educational decision-making (Turnbull \& Turnbull, 2000). In ESSA and the 2015 amendment to IDEA, the language shifted from "involvement" to "engagement", signaling a more meaningful role for parents. Shirley (1997) proposed this shift, explaining the use of the term involvement "avoids issue of power and assigns parents a passive role in the maintenance of school culture" (p. 73), whereas engagement

Corresponding Author:

Jamey Burho, Postdoctoral Research Associate, Oregon State University, 104 Furman Hall, Corvallis, OR, 97331, USA

Email: jamey.burho@oregonstate.edu 


\section{Parent Engagement for ELSWDS}

"designates parents as citizens in the fullest sense- change agents who can transform urban schools and neighborhoods" (p. 73). A body of research has documented barriers to meaningful parent engagement in decisions about special education services, particularly for ELs (e.g., Burke \& Goldman, 2018; Cobb, 2014; Cioè-Peña, 2020b). Little research focuses specifically on parent engagement for ELSWDs.

Regarding parent engagement on behalf of ELSWDs at the elementary level, one study by CioèPeña (2020b) indicates that racial discrimination pervades interactions between educators and Latinx mothers. However, no prior research focuses on parent engagement in reclassification decisions for secondary ELSWDs specifically. Given the critical nature of parent engagement in special education, combined with secondary ELSWDs' difficulty exiting EL services and the high stakes of earning credits to graduate, a close examination of reclassification decisions for secondary ELSWDs is warranted.

Given that little is known about how parents are engaged in reclassification decisions for secondary ELSWDs, we conducted a comparative case study to explore two research questions: (1) How do parents and educators communicate about reclassification decisions? and (2) How are parents engaged in reclassification decisions? To this end, we conducted six case studies of ELSWDs attending middle and high schools in a state in the U.S. Pacific Northwest. These students were either recently reclassified or were being considered for reclassification from EL services during data collection.

We begin this article by demonstrating that federal law stipulates greater parent engagement in special education decision-making than in decisions about EL services, where only parent notification is typically required. Next, we review the literature related to parent engagement in the special education and EL-service contexts, highlighting common obstacles. We then introduce our conceptual framework, contrasting one-way transmission models of parent-educator communication with reciprocal dialogue. As part of this framework, we consider how one-way modes of communication reflect cultural deficit thinking. After describing our methods, sites, participants, and analysis process, we describe findings. Specifically, we demonstrate that through their reliance on one-way transmission communication patterns, educators systematically excluded parents from meaningful decision-making about reclassification. Parents subverted this dynamic, however, by seeking information from their children and other family members to make informed decisions. Finally, we discuss implications, limitations, and directions for future research.

\section{Literature Review}

We contextualize our study in federal guidelines for engaging parents in special education and EL-service decision-making, as well as a long-standing literature documenting the oppression of parents of multilingual students. We end by reviewing literature concerning the unique challenges ELSWDs and their parents face.

Federal law outlines vastly different roles for parent engagement in special education versus EL services (see Table 1). In special education, IDEA stipulates parent engagement at every point in special education decision-making, from the initiation of eligibility evaluation, to consent for placement, to the drafting of IEP goals. By contrast, federal law stipulates a more limited decisionmaking role for parents of ELs (ESSA, \$1112(3), 2015). LEAs are required only to notify parents of ELs about relevant testing data and associated educational decisions, including the following: (1) results of the child's English language proficiency screener; (2) the school's available language instructional programs; (3) the parent's right to waive services; (4) ELP assessment results; and (5) the final EL-service exit decision. Some states and districts "consult" with parents about exiting decisions, but this is not required under federal law, and interpretations of this consultation practice differ and 


\section{Journal of Family Diversity in Education}

vary widely (e.g., California Department of Education, 2019; Minnesota Department of Education, 2017). A review of all 50 states' criteria for exiting students from EL services identified only four that included parent opinion or consultation as one of the criteria (Linquanti \& Cook, 2015).

Table 1

Parents' role in decisions about special education and EL services under federal law.

\begin{tabular}{|c|c|c|}
\hline & Special education services & English learner services \\
\hline Initial screening & $\begin{array}{l}\text { Either a parent of a child or the } \\
\text { school may initiate an initial } \\
\text { eligibility evaluation. Before } \\
\text { conducting an initial evaluation, } \\
\text { schools must obtain informed } \\
\text { consent from the child's parents } \\
\text { (IDEA, } \$ 300.300) \text {. }\end{array}$ & $\begin{array}{l}\text { Family member completes a home } \\
\text { language survey when initially registering } \\
\text { their child for school. If the family } \\
\text { member indicates the child uses a } \\
\text { language other than English to } \\
\text { communicate, the child takes the state's } \\
\text { English language proficiency screener } \\
\text { (ESSA, } \$ 3113 \text { (b)(2); USED, 2017). }\end{array}$ \\
\hline $\begin{array}{l}\text { Eligibility } \\
\text { determination }\end{array}$ & $\begin{array}{l}\text { Schools must include parents in } \\
\text { eligibility meetings where eligibility } \\
\text { decisions are made (IDEA, \$300.306). }\end{array}$ & $\begin{array}{l}\text { The LEA must notify the family of: the } \\
\text { child's ELP screener results. In addition, } \\
\text { if the child did not score proficient, the } \\
\text { LEA must notify the family of: } \\
\text { 1. Available language } \\
\text { instructional program options } \\
\text { (e.g., EL services). } \\
\text { 2. Their right to waive EL } \\
\text { services. } \\
\text { 3. Their right to remove their } \\
\text { child from EL services. } \\
\text { 4. Criteria for exiting EL } \\
\text { services (ESSA, } \$ 1112(3)(A))\end{array}$ \\
\hline $\begin{array}{l}\text { Establishing } \\
\text { educational goals }\end{array}$ & $\begin{array}{l}\text { Schools must ensure that parents are } \\
\text { present at each annual IEP meeting, } \\
\text { in which educational goals are } \\
\text { established and agreed upon by all } \\
\text { IEP team members, including } \\
\text { parents (IDEA, \300.321). Schools } \\
\text { must inform parents of ELSWDs as to } \\
\text { how EL services meet IEP goals } \\
\text { (IDEA, \$300.324). }\end{array}$ & $\begin{array}{l}\text { No specific process exists for establishing } \\
\text { educational goals for students classified as } \\
\text { ELs, other than notifying parents of the } \\
\text { criteria students must meet to exit EL } \\
\text { services. }\end{array}$ \\
\hline $\begin{array}{l}\text { Planning for } \\
\text { service delivery }\end{array}$ & $\begin{array}{l}\text { Schools must include parents in } \\
\text { eligibility meetings and follow-up } \\
\text { IEP meetings where special } \\
\text { education placement decisions are } \\
\text { made (IDEA, } \$ 300.306, \$ 300.322) \text {. }\end{array}$ & $\begin{array}{l}\text { No specific process exists for planning } \\
\text { for EL service delivery, other than } \\
\text { notifying parents of the available language } \\
\text { instruction educational programs and } \\
\text { their right to waive services. }\end{array}$ \\
\hline $\begin{array}{l}\text { Annual } \\
\text { assessment }\end{array}$ & $\begin{array}{l}\text { Schools must obtain informed } \\
\text { consent from parents to conduct } \\
\text { triennial reevaluations }(\$ 300.300) \text {, }\end{array}$ & $\begin{array}{l}\text { Students classified as ELs, including } \\
\text { those whose parents have waived EL } \\
\text { services, take the state's annual ELP }\end{array}$ \\
\hline
\end{tabular}




\section{Parent Engagement for ELSWDS}

\begin{tabular}{|c|c|c|}
\hline & $\begin{array}{l}\text { and parents must participate in the } \\
\text { annual IEP meeting in which } \\
\text { reevaluation results are discussed. At } \\
\text { these IEP meetings, parents participate } \\
\text { in decision-making for students' } \\
\text { continued goals and educational } \\
\text { placement (IDEA, } \$ 300.321 \text {, } \\
\$ 300.321 \text { ). }\end{array}$ & 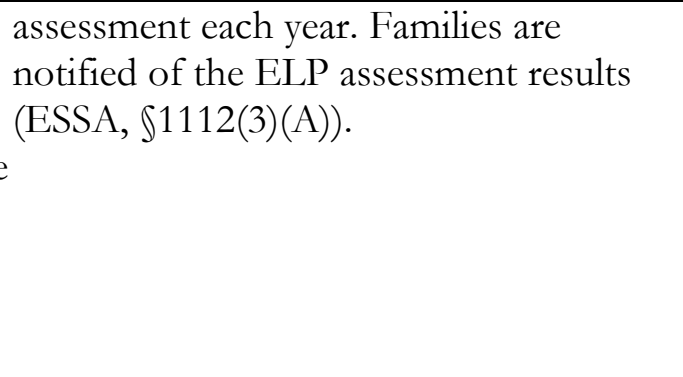 \\
\hline Exiting services & $\begin{array}{l}\text { Schools must ensure that parents are } \\
\text { present at each annual IEP meeting, } \\
\text { in which team members decide } \\
\text { whether a student should continue } \\
\text { to receive special education services } \\
\text { (IDEA, } \$ 300.321, \S 300.321)\end{array}$ & $\begin{array}{l}\text { Federal policy defines no specific role for } \\
\text { parents in making decisions about when } \\
\text { children should exit EL services. Some } \\
\text { states' policies require parent } \\
\text { consultation, but interpretations of } \\
\text { "consultation" vary (Linquanti \& Cook, } \\
\text { 2015). }\end{array}$ \\
\hline
\end{tabular}

We identified several studies that examine parent engagement in special education on behalf of students who are traditionally marginalized in schools. Students and their parents in these studies were described as culturally and linguistically diverse. Three recent reviews of relevant literature (Cobb, 2014; Harry, 2008; Wolfe \& Durán, 2013), plus two other peer-reviewed studies we located (Baker et al., 2010; Burke \& Goldman, 2018) indicated these parents face myriad challenges, including (1) language barriers, (2) incomplete or inaccessible information, and (3) oppression and marginalization. In contrast, almost no literature exists about any aspect of parents' participation in decisions about EL services, including the reclassification decision. The clearest way in which parents can exercise decision-making power regarding EL services is by waiving these services for their children. However, there is only very limited attention to this practice in the literature, with no descriptive research at the national, state, or even district level. ${ }^{1}$ In our review of the literature, we found only one study that explores parents' role in EL-service decision-making. Brooks (2019) described one Mexican-American mother's attempts to advocate for her son and have him exited from EL services. Like the marginalized parents in the special education studies, this mother lacked adequate information and school support to participate in meaningful engagement.

Research has demonstrated that educators who are not specialists in EL services or special education services often do not fully understand the relevant policies and services (Kangas, 2017a). Yet in order to be meaningfully engaged in key decisions about their children's education, parents of ELSWDs must learn about two complex sets of policies and services. For parents of multilingual students, including immigrant parents who did not attend U.S. schools themselves, engagement in educational decisions becomes even more challenging.

Scant research has specifically focused on parent engagement in reclassification decisions for ELSWDs. However, in the research that does exist about ELSWDs, a key theme that emerges is the fragmented nature of the educational landscape that these students and their parents face, with special education and EL services often viewed as competing needs (Kangas, 2017a, 2017b, 2018; Schissel \& Kangas, 2018). Special education and EL services each have separate federal legislation, separate funding streams, and separate teacher preparation systems. As Kangas (2017a) noted, "[T]eachers and specialists conceptualize their work in terms of boundaries corresponding to their own specialization - what they can or cannot do and which students they can or cannot support" (p. 267). This lack of collaboration among specialists, in addition to a failure to meaningfully engage ELSWD parents, might have serious consequences to instructional delivery. For example, IEP goals and 


\section{Journal of Family Diversity in Education}

accommodations developed on behalf of ELSWDs have been shown to lack research-based EL teaching practices, as well as details related to students' family cultural background, linguistic learning needs, and funds of knowledge (Hoover et al., 2018). Regarding reclassification in particular, Kangas and Schissel (2021) found that teachers disagree about the consequences of these decisions for ELSWDs. EL teachers believed reclassification promotes equity for ELSWDs, while special education teachers believed some students are pushed out of EL services and denied the language support they need.

Equity is a critical issue in reclassification for ELSWDs, especially considering how educators' cultural deficit thinking might influence this high-stakes decision point. Valencia (2010) defined cultural deficit thinking is a phenomenon in which poor students, students of color, and their families are marginalized and pathologized, especially in terms of students' perceived academic deficiencies. Cultural deficit thinking places the blame on these students and their families, rather than examining how schools are structured to disadvantage these students. Such oppression against ELSWDs and their families was another key theme that emerged in our review. In a study of ELSWD parent participation in IEP meetings, Cioé-Peña (2020a) reported these parents were relegated to a role of passive listeners and information-gatherers, and lacked opportunities to shape the agenda or ask questions. When different professionals cycled in and out of IEP meetings, parents were further devalued and silenced, and hindered in seeking clarity and making sense of the IEP as a whole. Institutional factors and stakeholders' deficit perspectives combined to systematically place ELSWDs in classes on lower academic tracks (Kangas, 2020; Kangas \& Cook, 2020). ELSWD parents, in turn, have internalized these deficit views, as Cioè-Peña (2020b) found in her study of elementary-age ELSWDs and their Latinx mothers. In confronting schools led by a majority of English-only speakers, these immigrant mothers doubted their own ability to advocate for their children. They also adopted deficit perspectives toward their own child's language and academic capabilities, likely owing to the fact that "discourse around their children as disabled is so central to their relationships with the schools" (p. 11).

\section{Conceptual Framework}

\section{Transmission vs. Reciprocal Dialogue in Communication between Educators and Parents}

To investigate communication between parents and educators about reclassification for ELSWDs, we drew on two key concepts from literature about home-school communication: transmission and reciprocal dialogue. Researchers have argued that meaningful involvement in educational decisions requires reciprocal dialogue, which involves bidirectional conversation (Ishimaru, 2017), in which "participants listen to one another and build on each other's words" (Bertrand, 2014, p. 814). Full implementation of IDEA requires this reciprocity, which is characterized by educators seeking out parents' perspectives on their children's strengths and needs, and parents learning about educational policies and available services (Kalyanpur et al., 2000).

By contrast, home-school communication typically follows a transmission model (Nichols \& Read, 2002). Schools notify parents of meetings, inform them of eligibility determinations, and send home assessment results, with information flowing unidirectionally from educators to parents. As Nichols \& Read (2002) stated: "The goal of communication, according to this perspective, is for information transmission to occur smoothly so that the receiver 'gets' the message intended by the transmitter" ( $p$. 51). Unfortunately, data has suggested that even within this more modest vision of home-school communication, schools are often not successful in transmitting key information to parents (National School Public Relations Association, 2011; Public Agenda, 2012). 


\section{Parent Engagement for ELSWDS}

It is perhaps not surprising that enacting the reciprocal dialogue mandated by IDEA poses serious challenges for all parties involved. Research has suggested that interactions between parents and teachers typically follow a diagnosis-prescription framework, which privileges teachers' perspectives and limits parents' ability to meaningfully engage (MacLure \& Walker, 2000; Nichols \& Read, 2002). As Nichols \& Read (2002) explained, "[P] arents invariably wait until the teacher has offered the 'diagnosis' before entering into dialogue; as a consequence, parents' contributions are framed as responses to the teacher's knowledge" (p. 54, emphasis added). Thus, the diagnosis-prescription model operates as a subset of the general transmission framework of communication, with educators seeking to transmit the diagnosis and prescription to parents.

A serious consequence of the transmission approach generally and the diagnosis-prescription framework specifically is the perpetuation of cultural deficit thinking, by which educators marginalize parents through the institutional power they hold. This issue is especially pervasive and problematic for parents of multilingual students (Mendoza \& Olivos, 2013). Traditional engagement approaches are biased toward White middle-class culture of schools and dismissive of potential contributions of parents of multilingual students (Baquedano- López et al., 2013). Despite good intentions, educators have constrained and silenced parents of multilingual students by shaping conversations around their own identities, ideologies, and interests (Barajas-López \& Ishimaru, 2020; Rocha-Schmid, 2010). Unfortunately, educators receive little training for critiquing their own engagement practices and facilitating reciprocal dialogue (Mapp \& Kuttner, 2013; Park \& Paulick, 2021).

In this study we explore the tension between transmission and reciprocal dialogue, analyzing ways in which educators and parents of English learner students with disabilities attempted to enact both and the challenges and opportunities that emerged.

\section{State Policy Context for Reclassification of English Learners with Disabilities}

In the state where this study took place, there have been a variety of recent policy developments that have impacted reclassification processes for ELSWDs. In the past, ELs in the state were typically reclassified if they scored proficient on the state ELP assessment. However, districts were allowed to consider additional criteria, such as teacher recommendations or additional assessment data. Some districts considered parent input as part of these additional criteria. Parent notification of reclassification decisions was required for all districts, but parent input was not. Additionally, until February 2019, the state allowed students, including ELSWDs, to be reclassified if a school-based team analyzed a portfolio of student work and determined that the student had demonstrated they would benefit from instruction in the regular education program without additional language support. In these cases, in which a student was allowed to exit EL services without having scored proficient on the state ELP assessment, parental input was required, though parent attendance at the team meeting was not.

The passage of ESSA in 2015 led to several policy changes. Most importantly, ESSA required that states implement "standardized, statewide entrance and exit procedures" for ELs. Thus, the state worked to build greater uniformity in EL reclassification processes across districts. Several state policy documents regarding reclassification have stated that Title III of ESSA requires districts to "include parents as active participants" during the reclassification process, but this directive has remained relatively open to interpretation by districts. Importantly, beginning in February 2019, the state began to require that all students, including ELSWDs, must have scored proficient on the state ELP assessment in order to be reclassified. Given the ambiguity about parents' role in the reclassification process, and given prior research demonstrating the marginalization of parents of multilingual learners in special education, the participation ELSWD parents in reclassification decisions merits attention. 


\section{Journal of Family Diversity in Education}

\section{Methods}

Our comparative case study (Merriam \& Tisdell, 2016) examined communication between parents and educators about services and reclassification for ELSWDs. This analysis is part of a larger qualitative study on reclassification decisions on behalf of ELSWDs. We investigated reclassification policy and six student cases across four school districts, comparing and contrasting cases across multiple locations to better understand individual cases (Stake, 2006). We grounded inquiry in participants' lived experiences to understand related social dynamics and little-studied situations and phenomena (Patton, 2015).

\section{Sites}

Our study took place in four school districts in a state in the Pacific Northwest. Charles, Landon, and Valley Districts serve small cities, while Allen District serves a town on the fringe of an urban area. These districts were chosen because they all had been part of state-wide conversations about reclassification policies for ELSWDs, and had adopted related reclassification practices, including the review of work samples and other relevant data. Moreover, these districts demonstrated variation across a number of factors, including size, geographic location, socioeconomic factors, and characteristics of their EL populations.

We conducted case studies in four schools across three of the districts, all of which enrolled ELs at a rate of $20 \%$ or more of their population: Creekside Middle School (Allen District), Shepherd Middle School (Allen District), Fletcher High School (Landon District), and Andrews High School (Valley District) (see Table 2).

\section{Table 2}

Key demographic information for participating school sites.

\begin{tabular}{|c|c|c|c|c|c|}
\hline School name & District & Location & $\begin{array}{l}\text { Student } \\
\text { enrollment }\end{array}$ & $\begin{array}{l}\text { English learner } \\
\text { enrollment }\end{array}$ & $\begin{array}{l}\text { Students } \\
\text { receiving free } \\
\text { or reduced- } \\
\text { price lunch }\end{array}$ \\
\hline Andrews HS & Valley & Town (fringe) & Small & $90 \%$ & $95 \%$ \\
\hline Creekside MS & Allen & City (small) & Medium & $20 \%$ & $30 \%$ \\
\hline Fletcher HS & Landon & City (small) & Large & $20 \%$ & $50 \%$ \\
\hline Shepherd MS & Allen & City (small) & Medium & $20 \%$ & $30 \%$ \\
\hline
\end{tabular}

Notes. Location is classified using NCES locale codes (USED, NCES, n.d.). Small cities are cities inside urbanized areas with populations of less than 100,000. Fringe towns are areas inside an urban cluster located less than 10 miles from an urbanized area. "Small" enrollment is $<500$, "Medium" enrollment is 500-1000, "Large" enrollment is $>1000$. The term "Ever English learners" denotes students who are currently English learners (enrolled in EL services) as well as former English learners who have been reclassified and no longer receive EL services.

We chose these sites based on recommendations from our district-level contacts, who helped us reach teachers who were involved in reclassification decisions on behalf of ELSWDs. Teachers then referred us to the parents of students who had been reclassified from EL services during the last two school years, or who would be considered for reclassification in the near future. 


\section{Parent Engagement for ELSWDS}

In the fourth district, Charles, we collected data related to our overarching focus, but did not conduct a case study. Charles District infuses secondary special education and content courses with targeted language support for ELSWDs, rather than always requiring ELSWDs to attend separate special education and ELD courses. Thus, EL status does not serve as a barrier to enrollment in content course in this district, and, perhaps for this reason, there was less urgency among educators to reclassify ELSWDs in this district, and reclassification of ELSWDs at the secondary level occurred less often. Interviews with teachers and administrators in this district informed our study by shedding light on district policies for engaging parents when reclassification decisions did occur.

Table 2 offers demographic information for each school site.

\section{Participants}

This study focused on six case study students, as shown in Table 3.

\section{Table 3}

\section{Case study student information.}

\begin{tabular}{|c|c|c|c|c|c|}
\hline Student & Site & District & Grade & $\begin{array}{l}\text { Reclassification } \\
\text { status }\end{array}$ & Disability \\
\hline Adrian & $\begin{array}{l}\text { Creekside } \\
\text { MS }\end{array}$ & Allen & 8 & $\begin{array}{l}\text { Reclassified January } \\
2019\end{array}$ & SLD \\
\hline Jessica & $\begin{array}{l}\text { Shepherd } \\
\text { MS }\end{array}$ & Allen & 8 & $\begin{array}{l}\text { Reclassified May } \\
2019\end{array}$ & $\mathrm{CD}$ \\
\hline Johnny & & & 11 & $\begin{array}{l}\text { Reclassified January } \\
2019\end{array}$ & $\mathrm{CD}$ \\
\hline Andrea & Fletcher HS & Landon & 11 & $\begin{array}{l}\text { Reclassified June } \\
2018\end{array}$ & $\mathrm{CD}$ \\
\hline Sebastian & & & 11 & $\begin{array}{l}\text { Reclassified January } \\
2019\end{array}$ & SLD \\
\hline Marcos & $\begin{array}{l}\text { Andrews } \\
\text { HS }\end{array}$ & Valley & 10 & $\begin{array}{l}\text { Reclassified June } \\
2017\end{array}$ & $\mathrm{CD}$ \\
\hline
\end{tabular}

Our purposeful sampling approach (Patton, 2015) allowed us to connect with students who met our study criteria. Case study students were either 8th graders attending middle school or $10^{\text {th }}$ or $11^{\text {th }}$ graders attending high school. All were identified with higher-incidence disabilities: three with a specific learning disability (SLD), and three with a communication disorder (CD). All case study students were of Mexican heritage. They received school instruction in English and had Spanish as a home language. One student was reclassified a year-and-a-half prior to this study, one was reclassified six months before data collection, and four were reclassified during our data collection (January 2019 and May 2019). By studying the cases of students who were at different stages in the reclassification process, we were able to capture data on parent engagement that spanned the decision process: (1) leading up to the decision, (2) during the decision-making process, and (3) after the decision, when the student continued to be monitored for academic progress.

In addition to the six case study students and their parents, we purposefully sampled (Creswell \& Poth, 2018) school- and district-based educators who worked directly with case study students, or who had expertise on the district's reclassification policy, or both. These participants included: 29 teachers (11 ESOL/ELD, 10 content area/general education, eight special education), 11 


\section{Journal of Family Diversity in Education}

administrators (six district-level, five school-level), and 14 other staff (eight speech and language pathologists, four high school counselors, one family liaison, and one instructional assistant).

\section{Data Collection}

The data in this article come from a larger qualitative study on reclassification decisions on behalf of ELSWDs. Data were collected over the course of eight months (November 2018-June 2019). The full scope of data collection included 78 semi-structured interviews with parents, students, teachers, and administrators. In this article, we focus our analysis on data most relevant to our case study research questions, which came from the following: (1) parent and educator interviews clustered around student cases, (2) educator interviews focused on reclassification policies, and (2) observations of reclassification meetings.

Students and their parents were interviewed twice (at the beginning and end of our data collection period). Interviews took place in their homes, except in the case of Andrea and her grandparents, who asked to be interviewed at the school. We asked parents about their engagement with educators before, during, and after the reclassification decision. Interviews with teachers and administrators took place at the school or district office and sometimes involved follow-up interviews. These professionals responded to questions about their experiences with reclassification decisions, their engagement with parents, and their experience working with the case study students. See Appendix A for the complete interview guides. We focus our discussion of the findings particularly on the cases of Adrian, Johnny, and Sebastian, since reclassification decisions on their behalf were made during the time frame of our data collection, and thus we gained the most direct evidence of parents' engagement in these three cases.

Reclassification meetings were an important and novel part of reclassification protocol in one district in our study, Landon. Due to the fact that parents were invited to reclassification meetings, and that these meetings offered a fuller picture of how parents were engaged in reclassification decisions, we observed two reclassification meetings on behalf of case study students Johnny and Sebastian. We also reviewed academic records for all case study students (including transcripts, EL exit forms, IEPs, work sample scoring rubrics, and school letters [sent to and often signed by parents]). We referred to these records while conducting interviews and while analyzing interviews and notes from observations of reclassification meetings.

We collected data in four districts that represented a range of policies regarding parent engagement in reclassification decisions. In Landon District, educators invited parents to reclassification meetings and prioritized their attendance. In Valley and Charles Districts, parents were invited to reclassification meetings but often did not attend, perhaps because parent attendance was not prioritized. In Allen District, reclassification meetings were not conducted. Further detail on this district variation in policy is offered later in this section.

\section{Data Analysis}

Strauss and Corbin's (1998) three-step coding scheme guided our iterative data analysis process. First, we conducted open coding by reviewing data, field notes, and memos line by line. We constantly compared these codes and their component data to decide how best to form our first set of codes. We next engaged in axial coding (Strauss \& Corbin, 1998), in which we reread our initial codes and their underlying data to draw connections among the codes and then organize codes into conceptual categories. Finally, we engaged in thematic building, in which we reread the axial codes we established in the previous step, and decided how the codes and code clusters related to each other, to develop a narrative based on these relationships (Strauss \& Corbin, 1998). During this final step of analysis, we compared aspects of home-school communication and parent engagement among sites and districts. 


\section{Parent Engagement for ELSWDS}

After inductively analyzing relationships among our axial codes, a pattern of one-way communication emerged across all six student cases, in which parents were systematically excluded from meaningful engagement. We then turned to the literature to explore theoretical frameworks that aligned with our data. Nichols and Read's (2002) model for understanding nuances in transmission and diagnosis-prescription patterns in home-school communication emerged as the most relevant to the communication patterns we discovered. Most of our final codes aligned with the "transmission" main code and "diagnosis-prescription" sub-code (MacLure \& Walker, 2000; Nichols and Read, 2002). Our approach aligns with the grounded theory method of prioritizing empirically generated conceptual categories and codes (Strauss \& Corbin, 1998). As we revised codes throughout the data analysis process, we re-coded all data to align with these subsequent changes. We conducted coding and analysis via the online application Dedoose.

The two authors jointly employed multiple validation strategies during coding and post-coding analysis. The first author conducted all interviews and document analysis, and assumed a chief coding role, due to her greater knowledge of participants and the school contexts. Consistent with the view that analysis is deeply intertwined with subjectivities that the positivistic concept of "inter-rater reliability" is not always appropriate in qualitative research (St. Pierre \& Jackson, 2014), we jointly engaged in multiple validation strategies of the initial coding, such as peer review and debriefing (Creswell \& Poth, 2018). In our peer debriefing, we shared our research process and preliminary findings with researchers at the state education agency. These representatives provided further insight on policies such as their own efforts to engage EL and ELSWD parents.

In our joint post-coding analysis, we strove to ensure the four main validity criteria of qualitative analysis, as laid out by Whittemore and colleagues (2001): credibility, authenticity, criticality, and integrity. Our analysis reflects credibility due to the effort we made to accurately interpret the meaning of interview and observation data. To this end, we used triangulation (Creswell \& Poth, 2018), such as checking interview reports from parents, teachers, and students against data found in student transcripts, test scores, IEPs, and school- and district-level policies. We conducted member checks (Creswell \& Poth, 2018) by sharing preliminary findings with administrators in each district. These leaders confirmed the patterns we identified and added insights related to context. For example, they explained how the review process of student work samples had evolved, and how engaging parents in reclassification meetings was a new undertaking for teachers. We also checked our findings with each case study student and parent during follow-up interviews, who confirmed and added further reflection, such as offering their personal evaluation of the reclassification process. This check helped the authors understand and correct their biases in data analysis.

We worked to establish authenticity by reflecting the lived experiences reported by participants. The subjectivity inherent in qualitative research required us to reflect on our values and ensure our interpretations were valid and grounded in the data. As part of building authenticity, we offered thick, detailed descriptions (Creswell \& Poth, 2018), including ample quotes from participant interviews, to back our interpretations. We engaged in self-critical reflection and demonstrated integrity as researchers. Our analysis involved recursive, repeated checks on our interpretations, described discrepant data in detail, and discussed disconfirming alternatives (Creswell \& Poth, 2018).

We maintained reflexivity of our assumptions, beliefs, values, and biases (Creswell \& Poth, 2018) by continually contemplating the influence of our personal and professional experiences. The first author, who conducted all interviews, is a special education researcher and former special education teacher. She was familiar with this study's district contacts through previous collaborative work. The second author, who helped design the study and collaborated on data analysis and writing, is a teacher educator and conducts research focused on multilingual students. She is a former bilingual teacher and speaks Spanish. Prior to the study, she had been an active participant in a statewide work group 


\section{Journal of Family Diversity in Education}

about reclassification for EL students with disabilities, collaborating alongside many of the district administrators in the study to discuss possible changes to policies and procedures.

When conducting interviews, the first author presented herself to participating teachers, families, and students as a university researcher, educator, and proficient Spanish speaker. In preparation for interviews, the first author reflected on her position as a high-status professional, and considered her biases as a White person representing dominant culture. She understood that study participants might guess what she wanted to hear, instead of disclosing more authentic perceptions. She also considered how her lack of personal understanding of the families' immigrant experiences might influence her own interactions with students and their families. The first author thus strove to develop rapport with all participants. She did so by meeting families at the location of their preference (in the parents' homes for four students, and at the student's school for two students), and spending about an hour before each interview sharing informal dialogue with the families and, when possible, observing students informally in their home environments. For example, in her interview with Johnny's parents, she met the entire family in their home and spoke to Johnny and his siblings about their personal interests. She also responded to questions from Johnny's parents about how she learned Spanish. The first author also conducted joint interviews with students and parents when participants stated that preference, as was the case with Johnny. The first author worked to facilitate interviews with respect and sensitivity, recognizing these interviews were not "neutral" or "objective" data collection experiences, but rather situated events in which participants would respond in ways that reflected their worldviews (Creswell \& Poth, 2018). Consequently, she approached each interview with the goal of thoughtfully and carefully listening to participants, taking the information as it unfolded and avoiding interpreting information through preconceived ideas (Creswell \& Poth, 2018). She and the second author maintained this reflective stance during data analysis. We regularly shared our reflections during joint analysis and peer debriefing, and logged and analyzed these reflections in memos.

\section{Findings}

In our analysis of home-school communication about parent engagement during reclassification, we found that educators chiefly conveyed information in a traditional, one-way manner, following the "transmission" model (Nichols \& Read, 2002). Communication reflected the "diagnosis-prescription" pattern of transmission (MacClure \& Walker, 2000), with educators diagnosing students' English proficiency level and prescribing the student's exit from ELD. A variety of barriers prevented parents and educators from engaging in reciprocal dialogue. Prime among these was the institutional power educators hold, consistent with previous research on asymmetrical power relationships between educators and parents of multilingual students (e.g., Baquedano-López et al., 2013; Mendoza \& Olivos, 2013). Parents frequently did not share their insights or concerns with educators. When making educational decisions, parents often did not rely on information educators shared with them but sought information from their children, relatives, and their own informal assessments. Parents were thus silenced, a pattern of marginalization that reflects educators' cultural deficit thinking.

Findings are organized into three sections. The first section addresses the educators' attempts at communication through "transmission", including through the "diagnosis-prescription" mode during reclassification. The second part describes communication from the parents' standpoint. Finally, we discuss promising instances of "reciprocal" dialogue.

\section{Educator Contribution: Transmission and Diagnosis-Prescription during Reclassification Decisions}




\section{Parent Engagement for ELSWDS}

To determine the effectiveness of educators' transmissions, we considered what case study parents understood following their interactions with educators. As explained in the beginning of this paper, when data was collected, educators in this particular state were allowed to consider work samples in reading, writing, listening, and speaking as part of a portfolio review, in addition to ELP test scores, to determine students' eligibility for reclassification. At the time of data collection, all four districts in our sample used these additional criteria when making reclassification decisions.

Evidence from our case studies suggested that educators' knowledge was privileged in reclassification decisions for ELSWDs. Specifically, the way in which educators transmitted information about reclassification decisions followed a diagnosis-prescription pattern (MacLure \& Walker, 2000; Nichols \& Read, 2002), with educators using school-based data to diagnose whether students were proficient in English and, if so, then prescribe reclassification out of EL services. This pattern was evident in reclassification meetings where parents attended, as in Landon District, and in reclassification decisions made without the parents' direct participation in a meeting, in the three other districts. Parents were effectively silenced through this dynamic.

\section{Diagnosis-prescription model of transmission during formal meetings.}

Just as MacLure \& Walker (2000) identified, the meetings we observed began with a brief, formal introduction, followed by "an unbroken stretch of talk" (p. 8) in which educators presented a diagnosis based on evidence and their professional judgment, which they "ran through" with the parent (p. 10). During these one-way conversations, educators attempted to transmit an immense amount of detailed, technical diagnostic information to parents, such as (1) scores from multiple tests, (2) rubrics with reclassification criteria for speaking, listening, reading, and writing, and (3) evaluations of student work based on these criteria.

The onus educators faced in conveying information may have prevented them from seizing opportunities to engage parents in reciprocal dialogue. For example, Sebastian's parent asked at the beginning of her son's meeting whether he might struggle in core content classes if he stopped receiving ELD. The administrator put up her hand and told the parent she would answer her questions after they reviewed Sebastian's work. Thus, the administrator asserted control over the conversation and deferred the parent's question until after the educators finished issuing their diagnosis and prescription, a discourse pattern documented in a variety of other parent-teacher meetings (MacLure \& Walker, 2000; Nichols \& Read, 2002).

Parents spent most of the reclassification meeting leaning toward the interpreter to receive simultaneous interpretation, a demand on parents' attention that seemed to silence parents. Educators used technical language (e.g., "increased complexity", "Level 4 designation", "phonetic structures"), a practice noted also by MacLure \& Walker (2000). For each ELP domain, educators reached consensus on a rubric-based score, before the administrator turned the discussion to the next domain. Educators solicited the parent's opinions and questions only at the end of the meeting, once all four domains had been discussed.

Before soliciting parents' opinions, educators' discourse in both meetings suggested they had already agreed as a team that the students should be exited. For example, at Johnny's meeting, the administrator said, "We'll review what we decided for each of the four domains and make a decision and thank the family for coming." Educators also used a celebratory and persuasive tone, such as when the administrator told Johnny's father, "I love seeing Dad smile" before they asked Johnny's father for his opinion. At the end of both Johnny's and Sebastian's meetings, after educators compared numerous work samples to proficiency standards for each domain, the administrator solicited the parent's opinion for the exit decision, thus offering the "diagnosis" before inviting parent participation. This pattern mirrored MacLure \& Walker's (2000) findings, where "the first occasion for parents to influence the agenda was at the end of the diagnosis" (p. 10). Johnny's father offered 


\section{Journal of Family Diversity in Education}

minimal response to educators' expert judgment (a pattern also noted by MacLure \& Walker [2000] among parents who require interpretation at diagnosis-prescription-style meetings). However, just like Sebastian's parent asked at the beginning of the meeting whether her son would regress without the ELD class, Johnny's father posed the same question when his opinion was solicited. The educators at the meeting explained the post-exit monitoring process to Johnny's father. Johnny's father then verbally assented to the prescription — of reclassification — issued by educators.

At the end of Sebastian's reclassification meeting, the parent attempted to break the educators' control of the diagnosis-prescription pattern by asking her son's opinion in front of the group. The educators listened as the parent and son engaged in this dialogue. However, the educators closed the conversation by persuading the parent to accept the exit decision, and did not address the parent's root concern.

Parent: Estoy entre "sî" y "no". Si en vez de avanzar, se estanca, y despues se va por atras... (I'm between "yes" and "no". If instead of advancing, he stagnates, and then he falls back...)

ELD teacher: (to Parent): What do you think will happen?

Parent: (in English) I want him to be on level, I'm worried he'll fall behind.

ELD teacher: How?

Parent: Estoy preocupada. (I'm worried.)

Administrator: It's a worry.

Special education teacher: I'll monitor grades, not just letting him go.

ELD teacher: If he starts to fall back, he can come back (to the ELD class) at any moment. That's why we call it monitoring.

Parent: (to Sebastian): (in English) How do you feel?

Sebastian: Me cae bien. (It's ok with me).

Parent: (to educators): Sure. (agreeing with exit decision)

ELD teacher: In every class, he can grow.

Special education teacher: In every class, he's doing great.

ELD teacher: (Sebastian) is confident about his ability.

Administrator: (ELD teacher) can always help, also (Special education teacher). (To Sebastian): If we decide to remove you (from EL services), these teachers (referring to all teachers at the table) aren't going anywhere. (to Parent): Mom, are you okay with this?

Parent: A tratar... (Let's try...)

Interestingly, in a follow-up interview, the same ELD teacher believed the parent had been effectively engaged in decision-making:

It was the parental and the student decision. We asked: 'What do you think?' And the mother asked, 'Is it the right decision? Is he going to be missing instruction?' It was explained to her what we would do, and he can always come back. And the student participated. I think it wasa true team decision.

Perhaps the fact that the educators heard from Sebastian's mother and her son-beyond the simple agreement that educators might be accustomed to from parents-might appear to be more like reciprocal dialogue than is typical in these decisions. Offering parents an opportunity to express their opinions during reclassification meetings is certainly a step closer to collaborative decision-making than merely notifying parents.However, Sebastian's parent believed the educators did not adequately answer her questions. As she explained in our follow-up interview,

Cuando (Sebastian) salga de ELD y en vez de seguir aprendiendo, vaya retrosándose en su aprendizaje porque le haga falta esa clase. ¿Qué contestó el maestro (de ELD)? 'A qué terefieres con eso?' De ahí no hubo una respuesta. Nada más dijeron, 'Vamos a ver en qué podemos ayudar a (Sebastian) o puede regresar paulatinamente a la clase del maestro (de ELD).When (Sebastian) 


\section{Parent Engagement for ELSWDS}

leaves ELD and instead of continuing to learn, he falls behind in his learning because he needed that class. How did the ELD teacher respond? 'What are you referring to?' From there, there wasn't an answer. They just told me, 'Let's see how we can help (Sebastian) or he can gradually regress back to the ELD teacher's class.'

In this instance, Sebastian's mother was raising a concern about the potential negative impact of the exit "prescription", just like Johnny's father did. The educators attempted to respond, but this parent did not feel heard, and she felt that the ELD teacher had been defensive in asking "What do you mean?" (The first author who observed had the same impression, that the ELD teacher's question was defensive, and that the ELD teacher and administrator were making an effort to convince the parent of the appropriateness of the exit decision.) Perhaps the parent felt unheard because the educators' reassurances did not offer enough information about subsequent monitoring. It is notable that in both Johnny's and Sebastian's cases, parents attempted to interrupt the diagnosis-prescription pattern of communication by raising a highly anticipatable concern: whether their child would regress academically after exiting ELD. Our findings here also parallel those of MacLure \&Walker (2000) in two respects. First, parents questioned a "good news" diagnosis by raising a concern or asking for information, perhaps because they were not convinced the educators had devoted significant attention to their child's need. Second, educators responded by controlling the conversation through explaining the subsequent monitoring process, rather than directly addressing and exploring the parent's concern.

\section{Diagnosis-prescription model of transmission outside formal meetings.}

In Allen District, where educators do not invite parents to take part in meetings about reclassification decisions, and in Charles and Valley Districts, where parents are invited but usually do not attend, home-school communication about reclassification also followed a diagnosis-prescription style of transmission. Educators from Charles District said their policy is to contact parents by phone to "get them on board" with the ELD exit decision. This stance clearly indicated educators' control of the diagnosis and prescription, and the potential silencing of parents' questions or dissenting opinions. Another Charles District administrator explained, "I'll contact parents and let them know that this kid was exited." Similarly, Jessica's ELD teacher (in Allen District) simply informed the parent that Jessica would be exited from ELD based on her scores. As this teacher said, "I just passed all my scores off to the facilitator so we can put them in envelopes and send them home."

Parents often did not successfully receive educators' transmissions of information about reclassification decisions. Parents of Jessica, Marcos, and Andrea were unaware their child had exited EL services and were no longer enrolled in ELD, despite having signed related consent forms. Sebastian's and Johnny's parents were unsure about the purpose of the reclassification meetings in follow-up interviews, since their child's annual IEP meeting were also scheduled within days of the reclassification meetings. This coincidence highlights the siloed nature of specialized service delivery and resulting confusion for parents.

Thus, in the context of reclassification decisions and formal reclassification meetings, educators attempted to transmit to parents a mass of detailed information using a diagnosis-prescription patterns of communication. Considering that federal law requires only parent notification in reclassification decisions, it is notable that educators in our study strove to gain parents' consent for these decisions, either within or outside the context of formal meetings. However, across contexts, parents' consent typically did not signal meaningful understanding of the decision, and their voices were silenced precisely at the point of decision-making.

\section{Parent Contribution: Often Silenced, but Also Resourceful}

In this second section, we shift from analyzing educators' role in reclassification to analyzing the voice and perspective of case study parents. We will explore examples of questions, concerns, and 


\section{Journal of Family Diversity in Education}

insights related to reclassification that parents communicated during interviews but did not communicate to educators. We discovered that case study parents felt silenced and marginalized by educators. Educators demonstrated cultural deficit thinking by failing to engage parents in meaningful conversation around reclassification decisions.

Adrian's parents did not understand they could waive their son's EL services - and thereby waive his ELD enrollment - until a relative informed them. Adrian's parent was disappointed with how her son's ELD teacher handled the exit decision the year before, when Adrian did not pass the portfolio review. As this parent explained, "La maestra le dio mucha esperanza a (Adrian). Por eso (Adrian) desespera." (The teacher gave a lot of hope to [Adrian]. For that reason, [Adrian] despaired.") This parent did not raise her concern with the teacher.

Sebastian's parent offered evidence that discrimination on the part of school personnel might have negatively impacted her communication with the school. For example, she complained during our interview that her son roamed the hallways during class. She felt the teachers isolated her son by allowing this behavior: "(Sebastian) tiene que estar en su clase. Pero en vez de hacer eso, lo que hacía era cerrar la puerta, por eso digo, él se sentía aislado." ("[Sebastian] needs to be in class. But instead of doing that, what [the teacher] did was close the door, and for that reason I say, [my son] felt isolated.") However, when two teachers complained about this same problem at the reclassification meeting, the parent smiled at her son and said nothing to the teachers.

This breakdown in communication between Sebastian's parent and the teachers might be due to another unvoiced complaint this parent shared during our interview: Sebastian told his mother that the ELD teacher once angrily said to him in class, "I'm going to send you back to Mexico." Sebastian asked his mother not to complain about this remark, to avoid reprisal. Sebastian's mother also explained she was reluctant to ask educators for help due to her family's position as immigrants: "A veces nos tiene como un poquito aislados de como pedir más ayuda o darnos información. Ese tipo de cosas... Es difícil porque todos somos inmigrantes." "“Sometimes they have us a little isolated for asking for help or giving us information. These types of things... It's difficult because we're all immigrants.") Sebastian's parent explained in a follow-up interview that during the five months since her son had been reclassified from ELD, she called the school repeatedly to learn about his progress, but her calls were not returned. Such a lack of communication effectively ended the conversation and silenced the parent.

Another interesting contrast between parent and teacher accounts in Sebastian's case, centered on Sebastian's habit of being talkative during class (a behavior observed by the first author). Sebastian's teachers complained about this habit, but his parent offered an interesting explanation during our interview—that Sebastian talks to avoid appearing unintelligent: "Y digo yo (a Sebastian), '¿Por qué hablas?' (Sebastian responde): 'Para que no piensen que estoy tonto. Porque todos hablan, saben escribir y leer y yo hablo para que no piensen que soy tonto."' (I say [to Sebastian], 'Why do you talk?' [Sebastian responds]: 'So they don't think I'm stupid. Because everyone talks, and knows how to write and read and I talk so they don't think I'm stupid."') During the reclassification meeting, as the parent sat listening to simultaneous interpretation, the administrator and teachers discussed how Sebastian's speaking was far clearer than his writing. The special education teacher hypothesized that Sebastian "was in a hurry during writing". The parent did not share her relevant insight regarding Sebastian's talk. If the parent had explained the purpose of Sebastian's frequent classroom talk, the team might have focused on Sebastian's social and emotional needs, and his resourcefulness in focusing on his relative strength in speech. Instead, the parent was silenced, perhaps due to her overall feeling of isolation, and the ELD teacher's previous discrimination toward her son.

Parents of all high school case study students expressed concerns during our interviews about whether their child would graduate, and about their child's options for work and study beyond graduation. However, parents did not share these concerns with educators. In particular, parents of 


\section{Parent Engagement for ELSWDS}

Johnny and Sebastian did not ask about their child's post-secondary options during reclassification meetings, even as educators discussed possible course options and advised students to visit their counselors to adjust their class schedules. This omission of such highly anticipatable parent questions is another example of educators' inadvertent silencing of parents.

Educators in our study explained that parents typically defer to educators' decisions for cultural reasons, or based on parents' lack of interest. Correspondingly, some parents in our study reported having deferred to teachers' expertise. As Adrian's father said, "Pues, no sabemos. Porque en realidad, los que tienen la experiencia son ellos, ¿no? No nosotros." ("Well, we don't know. Because is reality, those who have the experience are them [the educators], right? Not us.") However, our interview data indicate that parents might have deferred to educators' decisions even while they held dissenting opinions. For example, Sebastian's parent disagreed with how Sebastian's teachers had treated him, and she did not voice valuable insights about her son's behavior during reclassification meetings. Likewise, Adrian's mother believed her son should have been exited during the previous school year, but she did not share her opinion because she was countered by the educators and her husband. These examples highlight the ways in which parents might appear deferential while continuing to disagree with educators' decisions, perhaps for the sake of maintaining harmony with teachers and a school system on which they might depend for years to come.

It might seem that educators' silencing moves limited parents' ability to meaningfully engage in reclassification decisions. However, evidence from our study points to less apparent ways in which parents took an active, though behind-the-scenes, role in gathering information about their child's readiness to exit EL services. Parents in our study relied on their child's opinion about exiting ELD, such as when Sebastian's parent asked her son's opinion about the exit decision at the end of the reclassification meeting. Johnny's parent reported conversing with his son about exiting ELD before the reclassification meeting: "Yo le pregunté a (Johnny), dice, 'Sí, sí salgo de eso, sí, la hago. Sí puedo.." ("I asked [Johnny], and he says, 'Yes, I'll leave that, yes, I'll do it. Yes, I can."). Similarly, Adrian's parents said, "[Adrian] mencionó, 'Yo no quiero tener esa materia. Porque decía que lo trataban como si fuera un tonto." ("[Adrian] mentioned, 'I don't want that class.' Because he said they treated him as if he were stupid.") Adrian's parents also explained how they leaned heavily on their oldest son's opinion: "Su hermano habló con (Adrian) sobre esa clase también (ELD) y le dijo que no le convenía esa clase". ("His brother talked to him about that class [ELD], and told him that that class didn't suit him.")

Parents in our study also made informal, independent assessments of their children's ability to succeed without ELD. For example, Sebastian's parent expressed faith in her son's ability, saying, "Confío mucho en [Sebastian] y yo que soy su mamá y creo que [Sebastian] no va a necesitar regresar a la clase de (ELD)." ("I trust a lot in [Sebastian] and I'm his mother and I believe that [Sebastian] is not going to need to go back to the ELD class.")

\section{Evidence of Reciprocal Dialogue}

Most evidence in our study points to a one-way, transmission style of home-school communication in which educators systematically silenced parents. However, we also discovered glimmers of two-way, home-school dialogue.

Parents sometimes described educators as helpful and responsive. For example, Adrian's parents described asking school staff for tips on how they could further help their son at home. Marcos's parent explained how various educators regularly informed her and responded to her questions. Johnny's parent explained how he told his son's teachers not to push his son too hard, and that teachers responded with assurances that they would do all they could to help his child.

Educators described ways in which they felt they engaged parents in two-way dialogue about reclassification decisions. As a Landon District administrator explained about reclassification 


\section{Journal of Family Diversity in Education}

meetings, "If no one (from the family) shows up, it's hard to decide how to proceed." Another administrator explained, "It is finally the parent that decides whether they do agree with the exit or not." While obtaining consent and granting parents a sort of "veto power" might not strictly represent "reciprocal dialogue", this coordinated action among educators might be viewed as a positive step, especially considering educators' limited time, and the fact that laws surrounding EL services do not mandate parent consent.

Several educators cited instances when parents disagreed with an exit decision and asked that their child remain in ELD. As one administrator said, "I've had parents be the deal-breakers." Many educators expressed that they would like to build better relationships with parents and improve the quality of family engagement in reclassification decisions. As one ELD teacher said, "We would never make a decision in special education without the parent involved. I feel like ESL doesn't have those very rigid guidelines, but perhaps it should." Another teacher stated, "[Family engagement] is so foundational to what's going to take place in high school when the [ELSWD] kid can really get lost if the family is not actively involved." One administrator from Valley District suggested that the state department of education develop a flow chart to help guide educators in their engagement with ELSWD families around reclassification and other key decisions.

\section{Discussion}

\section{Key Findings}

Analysis of parent engagement in our six case studies demonstrates that while educators made efforts to engage parents of ELSWDs in reclassification decisions, these parents nonetheless faced systematic oppression in these home-school interactions, similar to those documented for culturally and linguistically diverse parents of children with disabilities, including language barriers and being silenced by educators. Analysis showed that home-school communication typically followed a oneway transmission pattern, with educators sending information to parents that was often not received as intended. Though two parents attended meetings, and all parents signed required forms, each parent nonetheless participated minimally in decisions, and some had incomplete information about key aspects of the reclassification decision. Communication in these decisions followed a diagnosisprescription pattern of transmission, with educators using school-based assessments and work samples to diagnose the student's English proficiency level and prescribe reclassification when appropriate. This diagnosis-prescription pattern occurred at reclassification meetings when parents were present and also in cases where parents received the diagnosis and prescription via a phone call or letter. This discourse pattern reflected cultural deficit thinking by marginalizing ELSWD parents: parents were severely limited in their ability to partner with educators or receive answers to their questions about reclassification decisions. Findings also showed that parents had important insights about their children that could have informed educational decisions but that parents did not voice, further demonstrating how these parents were silenced.

At the same time, analysis showed that parents often drew on non-school resources to support them in navigating educational decisions for their children. In particular, parents frequently used information from their child, their other children, and extended family members to inform their thinking about whether their child should exit EL services. This resourcefulness on the part of parents suggests the ineffective nature of traditional school-facilitated, home-school communication (at least from the viewpoint of parents), and the need for educators to engage parents in meaningful, productive two-way conversations.

\section{Implications for Policy and Practice}




\section{Parent Engagement for ELSWDS}

Our findings reveal a pressing need to establish more reciprocal patterns of communication between educators and parents of ELSWDs, as well as opportunities for meaningful parent engagement in reclassification decision-making. One potential strategy to foster reciprocal dialogue is to prioritize interactions between educators and parents outside of compliance-focused meetings, with a focus on relationship-building. While staffing and time constraints make this extremely challenging, a variety of initiatives have shown promise. For example, home visit programs, in which educators go to families' homes to learn more about their lives and hopes for the future, have shown potential to improve home-school communication and, ultimately, student outcomes (e.g., Johnson, 2014; Meyer \& Mann, 2011; Park \& Paulick, 2021; Sheldon \& Jung, 2018). To prepare for home visits, however, educators would require specific preparation to avoid "perpetuating an oppressive status quo" of traditional home-school interaction (Park \& Paulick, 2021, p. 1). In addition, family liaisons can serve as cultural brokers between home and school, helping parents feel more welcome, included, and able to ask question (Ishimaru, 2017). In home-based settings or in conversations with family liaisons, parents might have more opportunities to share information about their children's interests, passions, and post-secondary aspirations, laying the groundwork for more informed decision-making moving forward.

Another potential strategy to increase meaningful engagement in educational decisions for parents of ELSWDs is to provide additional professional learning opportunities for both pre-service and in-service teachers to increase their knowledge and skills in parent engagement, including learning opportunities focused specifically on engaging with parents of ELSWDs (e.g., Evans, 2013). These learning opportunities could center parent perspectives, for example by including videos with parents of ELSWDs describing questions they had about their child's services that educators did not address, insights they had about their children that they did not share with educators, and information or practices that would have been helpful to them. In addition, role plays or other active learning opportunities could help educators gain skills in enacting reciprocal dialogue.

In addition, IEP and reclassification meetings could potentially be combined so that children's progress and needs could be discussed by all stakeholders (students, parents, ELD teachers, special education teachers, content teachers, and administrators) in a more thoughtful and logical way. This combination could potentially streamline communication, minimize confusion, and ensure parents' engagement in reclassification decisions. Considering that IEP goals and accommodations on behalf of ELSWDs have been shown to lack attention to relevant cultural, experiential, linguistic, and family background information (Hoover et al., 2018), creating combined IEP and reclassification meetings might also be a logical step for creating truly individualized education plans that support these students as they transition to a "monitored" status of English language development.

Finally, in the next reauthorization of the Elementary and Secondary Education Act, we suggest that the role for parents within EL policy should potentially shift to more closely parallel the role for parents within special education. We do not think there is a compelling reason for parents of ELs to have fewer rights in educational decision-making for their children than parents of students with disabilities do. Rather than requiring only parent notification about key decisions in EL services, future EL policy could require that parents actively participate in decision-making about their children's services. Research in special education - and our own observations of reclassification meetings where parents were in attendance - clearly demonstrates that parent attendance at meetings does not ensure reciprocal dialogue or meaningful partnership in decision-making (e.g., Wolfe \& Durán, 2013). However, such partnership is impossible if only parent notification is required. This expanded role for parents in EL policy would undoubtedly pose complex implementation challenges. However, it would represent a meaningful shift to more fully recognizing parents of ELs, who frequently experience marginalization and oppression (e.g., Brooks, 2019; Castañeda v. Pickard, 1981; Cioé-Peña, 2020a), as true respected and valued partners in their children's education. 


\section{Journal of Family Diversity in Education}

\section{Limitations and Directions for Future Research}

It is notable that we observed reclassification meetings in only one school district (Landon), and within this school district, we only observed two reclassification meetings involving ELSWDs. However, parents do not typically attend reclassification meetings in other districts. In addition, it may not be possible to observe future reclassification meetings in any district, due to a recent policy change, which requires districts to use the ELP assessment as the sole criterion for exiting students from EL services.

Currently, there is extremely limited research on parent engagement in decisions about EL services generally and even less research about engagement for parents of ELSWDs. Future research is needed about these topics in other states and districts, across the full K-12 spectrum, and across a broader range of disability types. For example, further research is needed about the proportion of EL students whose parents waive EL services, variation in this proportion across contexts, reasons why parents waive services, and how parents learn about the option to waive services. Finally, more research is needed about instances in which reciprocal dialogue between parents and educators has occurred, particularly for parents of ELSWDs. Understanding the factors that enabled this reciprocal dialogue to occur, however fleeting, could inform future efforts to work towards more meaningful parent engagement-and a more responsive, just education system.

\section{Author Note}

The research reported here was made possible in part by a grant from the Spencer Foundation (\#201600112). The views expressed are those of the authors and do not necessarily reflect the views of the Spencer Foundation.

\section{References}

Baker, D. L., Miller, E., Dang, M. T., Yaangh, C. S., \& Hansen, R. L. (2010). Developing culturally responsive approaches with Southeast Asian American families experiencing developmental disabilities. Pediatrics, 126(Supplement 3), S146-S150.

Baquedano- López, P., Alexander, R.A. \& Hernandez, S. J. (2013). Equity issues in parental and community involvement in schools: What teacher educators need to know. Review of Research in Education. 37. 149-182.

Barajas-López, F. \& Ishimaru, A.M. (2020). "Darles el lugar": A place for nondominant family knowing in educational equity. Urban Education. 55(1). 38-65.

Bertrand, M. (2014). Reciprocal dialogue between educational decision makers and students of color: Opportunities and obstacles. Educational Administration Quarterly, 50(5), 812-843.

Brooks, M. D. (2019). A mother's advocacy: Lessons for educators of long-term EL students. In H. A. Linville \& J. Whiting (Eds.), Advocacy in English language teaching and learning (pp. 175-189). New York: Routledge.

Burke, M. M., \& Goldman, S. E. (2018). Special education advocacy among culturally and linguistically diverse families. Journal of Research in Special Educational Needs, 18(S1), 3-14. https://doi.org/10.1111/1471-3802.12413.

California Department of Education. (2019, January 18). Updated reclassification guidance for 201819. Retrieved from https://www.cde.ca.gov/sp/el/rd/reclassguide1819.asp.

Castañeda v. Pickard, 1981. 648 F.2d 989.

Cobb, C. (2014). Critical entanglement: Research on culturally and linguistically diverse parental involvement in special education 2000-2010. Exceptionality Education International. 23(1). 40-58.

Cioè-Peña, M. (2020a). Planning inclusion: The need to formalize parental participation in individual education plans (and meetings). The Education Forum. 1-14. 


\section{Parent Engagement for ELSWDS}

Cioè-Peña, M. (2020b). Raciolinguistics and the education of emergent bilinguals labeled as disabled. The Urban Review. 1-27.

Creswell, J.W. and Poth, C.N. (2018). Qualitative inquiry and research design: Choosing among five approaches. 4th Ed. Thousand Oaks, CA: Sage.

Evans, M. P. (2013). Educating preservice teachers for family, school, and community engagement. Teaching Education, 24(2), 123-133.

Every Child Succeeds Act (ESSA). (2015). Public Law No. 114-95, S.1177, 114th Cong.

Flores, S. M., \& Drake, T. A. (2014). Does English language learner (ELL) identification predict college remediation designation?: A comparison by race and ethnicity, and ELL waiver status. Review of Higher Education, 38(1), 1-36.

Harry, B. (2008). Collaboration with culturally and linguistically diverse families: Ideal versus reality. Exceptional Children. 74(3). 372-388.

Hoover, J. J., Erickson, J. R., Patton, J. R., Sacco, D. M., \& Tran, L. M. (2018). Examining IEPs of English learners with learning disabilities for cultural and linguistic responsiveness. Learning Disabilities Research \& Practice, 34(1), 14-22.

Individuals With Disabilities Education Act, 20 U.S.C. \300.307, \ 300.308, § 300.311 (2015).

Ishimaru, A. M. (2017). From family engagement to equitable collaboration. Educational Policy. 33(2). 350-385.

Johnson, E. J. (2014). From the classroom to the living room: Eroding academic inequities through home visits. Journal of School Leadership. 24(2). 357-385.

Kalyanpur, M., Harry, B., \& Skrtic, T. (2000). Equity and advocacy expectations of culturally diverse families' participation in special education. International Journal of Disability, Development and Education, 47(2), 119-136.

Kangas, S.E. (2017a). A cycle of fragmentation in an inclusive age: The case of English learners with disabilities. Teaching and Teacher Education, 66(1), 261-272.

Kangas, S.E. (2017b). "That's where the rubber meets the road": The intersection of special education and bilingual education. Teachers College Record, 119(7), 1-36.

Kangas, S.E. (2018). Why working apart doesn't work at all: Special education and English learner teacher collaborations. Intervention in School and Clinic, 54(1), 31-39.

Kangas, S. E. (2020). Counternarratives of English learners with disabilities. Bilingual Research Journal, 1-19. https://doi.org/10.1080/15235882.2020.1807424

Kangas, S.E. \& Cook, M. (2020). Academic tracking of English learners with disabilities in middle school. American Educational Research Journal. 20(10). 1-35.

Kangas, S.E. \& Schissel, J.L. (2021). Holding them back or pushing them out?: Reclassification policies for English learners with disabilities. Linguistics and Education, 63, 1-11.

Linquanti, R., \& Cook, H. G. (2015). Re-examining reclassification: Guidance from a national working session on policies and practices for exiting students from English learner status. Washington, DC: Council of Chief State School Officers.

MacLure, M., \& Walker, B. M. (2000). Disenchanted evenings: The social organization of talk in parent-teacher consultations in UK secondary schools. British Journal of Sociology of Education, 21(1), 5-25.

Mapp, K. L. \& Bergman, E. (2019). Dual capacity-building framework for family-school partnerships (Version 2). Retrieved from: www.dualcapacity.org.

Mendoza, M. \& Olivos, E. (2013). Latino parent involvement and the school system: Deconstructing isolation and inequality. The Education of the Hispanic Population: Selected Essays. Ed. Richard R. Verdugo. 171-186. 


\section{Journal of Family Diversity in Education}

Merriam, S.B. \& Tisdell, E. J. (2016). Qualitative research: A guide to design and implementation. $4^{\text {th }}$ ed. San Fransisco, CA: Jossey-Bass.

Meyer, J. A., Mann, M. B., \& Becker, J. (2011). A five-year follow-up: Teachers' perceptions of the benefits of home visits for early elementary children. Early Childhood Education Journal. 39(3). 191-196.

Minnesota Department of Education. (2017). Additional EL exit criteria decision tree. Retrieved from https://education.mn.gov/mdeprod/groups/educ/documents/hiddencontent/bwrl/mdcz/ $\sim$ edisp/mde073276.pdf.

National School Public Relations Association. (2011). National survey pinpoints communication preferences in school communication. https://www.nspra.org/files/docs/Releasepercent20onpercent20CAPpercent20Survey.pdf.

Nichols, S., \& Read, P. (2002). "We never knew it was that bad": Parent-school communication about children's learning difficulties. Australian Journal of Language and Literacy, 25(3), $49-64$.

Park, S. \& Paulick, J. (2021). An inquiry into home visits as a practice of culturally sustaining pedagogy in urban schools. Urban Education, 47(4), 801-834.

Patton, M.Q. (2015). Qualitative research and evaluation methods. $4^{\text {th }}$ ed. Thousand Oaks, CA: Sage.

Public Agenda. (2012). Boosting parental involvement: Results from a national survey of parents. http://www.publicagenda.org/pages/engaging-parents.

Rocha-Schmid, E. (2010). Participatory pedagogy for empowerment: A critical discourse analysis of teacher-parents' interactions in a family literacy course in London. International Journal of Lifelong Education. 29(3). 343-358.

Schissel, J. L., \& Kangas, S. E. (2018). Reclassification of emergent bilinguals with disabilities: The intersectionality of improbabilities. Language Policy, 17(4), 567-589.

Sheldon, S. B., \& Jung, S. B. (2018). Student outcomes and parent-teacher home visits. Baltimore, MD: Center on School, Family, \& Community Partnerships, Johns Hopkins University. Retrieved from http://www.pthvp.org/wp-content/uploads/2018/12/18-11-30-StudentOutcomes-and-PTHV-Report-FINAL.pdf

Shirley, D. (1997). Community organizing for urban school reform. Austin, TX: University of Texas Press.

St. Pierre, E.A. \& Jackson, A.Y. (2014). Qualitative data analysis after coding. Qualitative Inquiry. 20(6). 715-719.

Stake, R.E. (2006). Multiple case study analysis. New York, NY: Guilford Press.

Strauss, A., \& Corbin, J. (1998). Basics of qualitative research: Techniques and procedures for developing grounded theory. Thousand Oaks, CA: Sage.

Turnbull, A. \& Turnbull, R. (2000). Families, professionals, and exceptionality: Collaborating for empowerment. (4th ed.). Upper Saddle-River, NJ: Prentice Hall.

Umanski, I.M., Thompson, K.D., \& Diaz, G. (2017). Using an ever-English learner framework to examine disproportionality in special education. Exceptional Children, 84(1), 76-96.

U.S. Department of Education. (2017). English learner toolkit for state and local education agencies. Retrieved from https://ncela.ed.gov/files/english_learner_toolkit/OELA_2017_ELsToolkit_508C.pdf

U.S. Department of Education, National Center for Education Statistics. (n.d.). Rural education in America. Retrieved from https://nces.ed.gov/surveys/ruraled/definitions.asp

Valencia, R. R. (2010). Dismantling contemporary deficit thinking: Educational thought and practice. Routledge.

Whittemore, R., Chase, S.K., \& Mandle, C.L. (2001). Validity in qualitative research. Qualitative Health Research. 11. 522-537.

Wolfe, K., \& Durán, L. K. (2013). Culturally and linguistically diverse parents' perceptions of the IEP process: A review of current research. Multiple Voices for Ethnically Diverse Exceptional Learners, 13(2), 4-18. 


\section{Parent Engagement for ELSWDS}

\section{Notes}

${ }^{1}$ Flores and Drake (2014) do include "waiver status" as a variable in their state-level analysis of the relationship in Texas between EL classification and later need for remediation in college. The authors note that EL students whose parents have waived services represent "a distinct and highly underevaluated" group (p. 13), but they do not focus on analyzing the prevalence of this practice. 